Zeszyty Naukowe Szkoły Głównej Gospodarstwa Wiejskiego w Warszawie

Problemy Rolnictwa Światowego tom 18 (XXXIII), zeszyt 2, 2018: 105-116

DOI: $10.22630 /$ PRS.2018.18.2.38

Joanna Jaroszewska ${ }^{1}$ Wlodzimierz Rembisz $^{2}$

Instytut Ekonomiki Rolnictwa i Gospodarki Żywnościowej - Państwowy

Instytut Badawczy w Warszawie

\title{
Różnice w wydajności pracy między grupami państw UE w rolnictwie na podstawie Rachunków Ekonomicznych dla Rolnictwa (RER)
}

\section{The Differences of Labor Productivity in the EU Group of Countries in Agriculture Based on Economic Accounts for Agriculture (EAA)}

\begin{abstract}
Synopsis. Różnice w poziomie wydajności pracy w rolnictwie państw UE stawiają w gorszej sytuacji państwa przyjęte do UE po 2004 roku (UE-13). Wyprowadzone ujęcie analityczne tego problemu zostało zilustrowane empirycznie. Analizowaną wydajność pracy przedstawiono jako wartość dodaną brutto na jednego pełnozatrudnionego. Do badania wykorzystano Rachunki Ekonomiczne dla Rolnictwa oraz Statystykę Rolniczych Nakładów Pracy. Z badań wynika, iż duże różnice w wydajności pracy między grupami państw nadal się utrzymują jednakże następuje stopniowe ich zmniejszenie. Stwierdzono również negatywny wpływ dopłat bezpośrednich na ten proces.
\end{abstract}

Słowa kluczowe: wydajność pracy, zróżnicowanie, UE

\begin{abstract}
The differences of the level of labour productivity in EU countries puts at a disadvantage countries adopted into the EU after 2004 (EU-13). A derived analytical approach to this problem has been illustrated empirically. The labour productivity analysed is presented as gross value added per person employed. The Economic Accounts for Agriculture and the Agricultural Labour Input were used for the study. The research shows that the large differences of labour productivity between groups of countries is still maintained. However, it is gradually decreasing. A negative impact of direct payments on this process was also found.
\end{abstract}

Key words: labour productivity, diversification, EU

JEL Classification: J43, O13

\section{Wprowadzenie}

Wydajność czynnika pracy w oczywisty sposób jest uznawana w literaturze za jeden z istotnych źródeł określających jej wynagrodzenie oraz wzrost gospodarczy. Równocześnie uznawana jest za podstawowy wyznacznik zdolności konkurencyjnej gospodarek i sektorów ${ }^{3}$

\footnotetext{
${ }^{1}$ mgr inż., IERiGŻ-PIB, Zakład Ogólnej Ekonomiki Rolnictwa, Instytut Ekonomiki Rolnictwa i Gospodarki Żywnościowej - PIB, ul Świętokrzyska 20,00-002 Warszawa, e-mail: joanna.jaroszewska@ierigz.waw.pl; https://orcid.org/0000-0003-3733-4082

${ }_{2}^{2}$ prof. dr hab., IERiGŻ-PIB, Zakład Zastosowań Matematyki w Ekonomice Rolnictwa, Instytut Ekonomiki Rolnictwa i Gospodarki Żywnościowej-PIB, ul Świętokrzyska 20, 00-002 Warszawa,

e-mail: wlodzimierz.rembisz@ierigz.waw.pl; https://orcid.org/0000-0001-9941-3398

${ }^{3}$ Do tych kwestii nie odnosimy się w niniejszym artykule.
} 
(Gołaś, Kozera, 2008; Mrówczyńska-Kamińska, 2013; Misala, Ślusarczyk, 1999; Poczta, 2003; Latruffe, 2010; European Commission, 2008; OECD, 2011). Przyjmuje się, że występuje niższa wydajność pracy w gospodarkach i sektorach rolnictwa krajów, które są członkami wspólnoty dopiero od 2004 roku. Jak można założyć, ta sytuacja przesądza o niższym wynagrodzeniu czynnika pracy $\mathrm{w}$ gospodarce $\mathrm{i}$ w rolnictwie, $\mathrm{w}$ grupie państw nowoprzyjętych oraz jak wynika z literatury o trudniejszej sytuacji ekonomiczno-dochodowej gospodarstw rolnych w tych państwach (Gołaś, Kozera, 2008). Badania nad zróżnicowaniem wydajności pracy głównie w sektorze rolnictwa pomiędzy gospodarkami krajów starej UE, a nowoprzyjętymi po 2004 roku, prowadzili między innymi: Baer-Nawrocka, 2010; MartínRetortillo, Pinilla, 2012; Bear-Nawrocka i Markiewicz, 2010; Gutierrez, 2000. Były to jednakże badania prowadzone $\mathrm{w}$ bardziej zdezagregowanym ujęciu. W niniejszym artykule do kwestii różnic w wydajności czynnika pracy, w pierwszej kolejności odnosimy się do ujęcia analitycznego, a następnie przedstawiamy problem graficznie, bazując na podstawie teoretycznej funkcji produkcji. Jednocześnie weryfikując rolę cen produkcji rolniczej oraz rolę dopłat bezpośrednich $\mathrm{w}$ określonych grupach państw. Tym ujęciem wnosimy nową wartość do kwestii analizy wynagrodzeń czynnika pracy, tu odnośnie grup krajów UE o różnym poziomie rozwoju gospodarczego.

\section{Cel i przedmiot badania}

Celem artykułu jest pokazanie różnic $\mathrm{w}$ poziomie wydajności pracy $\mathrm{w}$ ujęciu realnym i nominalnym $\mathrm{w}$ rolnictwie $\mathrm{w}$ dwu grupach państw UE tj. $\mathrm{w}$ grupie krajów „starej” UE (UE-15) i nowo przyjętych państw po 2004 roku (UE-13) na podstawie Rachunków Ekonomicznych dla Rolnictwa (RER). Wyprowadzone ujęcie analityczne odnośnie wydajności czynnika pracy zostanie zilustrowane empirycznie. W ten sposób zostanie zaprezentowany potencjał informacyjny gromadzony w Rachunkach Ekonomicznych dla Rolnictwa. Artykuł ma zatem charakter metodyczno-analityczny oraz ilustracyjnoempiryczny w ramach przyjętego podejścia. Odnosi się do jednej z najważniejszych zmiennych ekonomicznych, determinujących $\mathrm{w}$ podstawowej części zamożność społeczeństwa. W rozumowaniu nie wykraczamy poza wyprowadzone wzory oraz wynikającą stąd ilustrację empiryczną.

Przyjmujemy hipotezę, iż występują widoczne i nie zmniejszające się różnice między obiema analizowanymi grupami krajów, jeśli idzie o wydajność czynnika pracy zarówno w ujęciu realnym jak i nominalnym. Celem weryfikacji tej hipotezy podjęto próbę określenia wpływu cen produktów rolnych na wydajność pracy w ujęciu nominalnym, jako faktycznego źródła finansowania wynagrodzenia czynnika pracy w jednej grupie krajów kosztem drugiej ${ }^{4}$. Jak również podjęto próbę zbadania roli dopłat bezpośrednich, jako podstawowego źródła finansowania wynagrodzenia pracy. W pracy przyjęto pewne uproszczenie, ponieważ analizowane są średnie arytmetyczne dla grup państw starej UE (UE-15) oraz państw przyjętych do UE po 2004 roku (UE-13) $)^{5}$. Ze względu na wewnętrzne

\footnotetext{
${ }^{4}$ Można by przyjąć implicite, iż ceny produktów były względem tego wskaźnika neutralne, czyli - w domyśle wszystkie analizowane kraje jednakowo skorzystały z integracji. Uważamy również, iż dopłaty, jako podstawowe źródła finansowania wynagrodzenia czynnika pracy, były w tym względzie dość neutralne i nie wpłynęły na zmniejszenie czy zwiększenie zróżnicowania, co jest także hipoteza poboczną.

${ }^{5}$ Kraje nowo przyjęte po 2004 roku to: Malta, Cypr, Republika Czeska, Słowacja, Węgry, Polska, Słowenia, Litwa, Łotwa i Estonia, natomiast w 2007 przystapiły Bułgaria i Rumunia, a w 2013 roku Chorwacja.
} 
zróżnicowanie obu grup państw, pod względem kierunków produkcji, warunków przyrodniczych, zróżnicowanych wielkości nakładów pracy, należy traktować niniejszą analizę jako pewne przybliżenie ${ }^{6}$. Wykorzystane zostały dwa źródła unijnych danych statystycznych, a mianowicie Rachunki Ekonomiczne dla Rolnictwa (RER) - Economic Accounts for Agriculture (EAA) oraz Statystyka Rolniczych Nakładów Pracy - Agricultural Labour Input (ALI). Rachunki Ekonomiczne dla Rolnictwa dotyczą całego sektora rolnego. Sporządzane są według jednolitej metodologii opracowanej przez EUROSTAT ${ }^{7}$, co uprawnia do porównań sytuacji ekonomicznej rolnictwa pomiędzy krajami Wspólnoty. W niniejszej analizie wykorzystano wartość dodaną brutto (WDB) ${ }^{8}$ (z RER) w cenach bieżących i stałych $(2005=100) \mathrm{w}$ mln euro, wytworzoną w rolnictwie poszczególnych grup krajów. Dla potrzeb analizy pomniejszono (lub nie) te wartość o wysokość dopłat bezpośrednich $^{9}$. Dane co do zatrudnienia (nakładów) czynnika pracy w rolnictwie ${ }^{10}$ zostały zaczerpnięte jak wspomnieliśmy z ALI i zostały wyrażone w tys. AWU ${ }^{11}$. Wydajność pracy w rolnictwie wyrażono relacją wartości dodanej brutto do nakładów czynnika pracy. Analiza obejmuje lata 1998-2016 z uwzględnieniem dostępności poszczególnych danych krajowych.

\section{Ujęcie wydajności pracy w cenach stałych i bieżących z uwzględnieniem dopłat i bez dopłat}

Przyjmijmy, iż istnieje funkcja produkcji o następującej postaci:

$$
y=f\left(L, x^{\prime}, n^{\prime}\right)
$$

gdzie:

$y-$ produkt,

$L$ - czynnik pracy,

\footnotetext{
${ }^{6}$ Przyjęcie takiego uproszczenia czyli oparcie analizy na średnich arytmetycznych może prowadzić do względnej nadinterpretacji otrzymanych wyników.

${ }^{7}$ Metodologia Rachunków Ekonomicznych dla Rolnictwa dostęna jest na stronie EUROSTAT: http://ec.europa.eu/eurostat/cache/metadata/en/aact esms.htm

${ }^{8}$ Wartość dodana brutto to wartość produkcji sektora rolnego pomniejszona o wartość zużycia pośredniego (nawozy mineralne, środki ochrony roślin, pasze, energia, paliwo, materiał siewny, usługi weterynaryjne, usługi rolnicze i inne).

${ }^{9}$ Dopłaty bezpośrednie ulegały zmianie $\mathrm{w}$ badanych latach co do wielkości oraz co do przedmiotu dopłat w zależności od ewolucji WPR i bieżacych uwarunkowań na danych rynkach. Jako przykłady dopłat można wymienić jednolitą płatność obszarową, oddzielną płatność z tytułu cukru (płatność cukrowa) czy płatności uzupełniajace takie jak np. płatność uzupełniajaca dla producentów surowca tytoniowego (płatność niezwiązana do tytoniu) oraz wsparcie specjalne jak np. specjalna płatność obszarowa do powierzchni uprawy roślin strączkowych i motylkowatych drobnonasiennych. W RER do WDB zalicza się płatności związane z produkcją, nie wlicza sie np. płatności dla młodych rolników oraz płatności związanych z PROW.

${ }^{10}$ Nakłady pracy w rolnictwie to praca opłacana (praca pracowników najemnych stałych i dorywczych) oraz praca nieopłacana (praca członków rodziny i pomoc sąsiedzka).

${ }^{11}$ Roczna jednostka pracy (AWU) oznacza ekwiwalent pełnego etatu. Oblicza się ją przez podzielenie liczby godzin przepracowanych $\mathrm{w}$ ciągu roku przez roczną liczbę godzin odpowiadająca pełnemu etatowi. W Polsce zastosowano jednostke pracy równą 2120 godzin pracy w roku, tzn. 265 dni roboczych po 8 godzin pracy dziennie. Przy wyliczaniu nakładów pracy wyrażonych w AWU (zgodnie z metodologią Eurostatu) zachowano warunek, że na 1 osobę nie może przypadać więcej niż 1 AWU, nawet jeżeli w rzeczywistości pracuje ona dłużej.
} 
$x^{`}$ - pozostałe materialne czynniki produkcji (wektor zaangażowania kapitału fizycznego oraz czynnika ziemi),

$n^{`}$ - pozostałe niematerialne czynniki (wektor miękkich uwarunkowań jak organizacja, postęp, wiedza, polityka rolna, ekonomiczna itp.).

Funkcja ta implicite definiuje przedmiot naszej analizy tj. jest podstawą określania relacji między produkcją a czynnikiem pracy, co jest istotą wydajności pracy. Na tej podstawie, przy pozostałych nakładach czynników jako danych ceteris paribus możemy dla celów naszej analizy, przyjąć następującą zależność tożsamościową :

$$
y=L \cdot \frac{y}{L}=L \cdot w_{L}
$$

Czyli, produkcja jest określona przez wielkość zatrudnienia czynnika pracy oraz jego ilościową (realną) wydajność przeciętną ${ }^{12}$. Następnie po wyizolowaniu wskaźnika wydajności czynnika pracy i ujęciu go wartościowo, czyli po uwzględnieniu cen produktów, zapisujemy jako:

$$
w_{L}^{*}=\frac{y \cdot p_{y}}{L}=\frac{y^{*}}{L}
$$

co definiuje wartościową (nominalną) wydajność czynnika pracy ${ }^{13}$. Wysokość tego współczynnika tj. $w_{L}^{*}$ jest faktycznym źródłem finansowania wynagrodzenia usług czynnika pracy, zaś wysokość $w_{L}$ jest jego podstawą efektywnościową. Wysokość współczynnika określonego wzorem (3) jest wrażliwa na zmiany cen produktów. Zmiany cen produktów mogą zatem zwiększać lub zmniejszać podstawę finansowania wynagrodzenia czynnika pracy, zasadniczej części dochodów w rolnictwie. Kwestią więc pozostaje jak jest wyrażony licznik tego współczynnika: $w_{L}^{*}$. Przyjmujemy, że może to być wartość dodana brutto: $\left(y^{*}\right)$. Przyjmujemy również iż, raz może być wyrażona w cenach stałych: $y_{(s)}^{*}=y$. $p_{y s}$; lub w cenach bieżących: $y_{(b)}^{*}=y \cdot p_{y b}$. Po wtóre, należy uwzględnić dopłaty: $y_{(s d)}^{*}=$ $\left(y \cdot p_{y s}+d\right)$ oraz $y_{(b d)}^{*}=\left(y \cdot p_{y b}+d\right)$. Zatem mamy kilka sposobów, biorąc pod uwage dane empiryczne RER, wyrazu wydajności czynnika pracy, jeśli idzie o ujęcie licznika we wzorze (3). Mianowicie: wydajność pracy mierzona jako iloraz wartości dodanej brutto w cenach stałych (realna), w cenach bieżących (nominalna), bez i z dopłatami. Odnoszone jest to do wielkości zatrudnienia (nakładów) czynnika pracy czyli zmiennej $L$. Ta zaś zmienna w RER ujmowana jest jak wspomnieliśmy na podstawie danych ALI w jednostkach AWU.

Stosownie do tego, tj. głównie różnych ujęć licznika w we wzorze (3) pokażemy dalej ilustrację empiryczną, będącą podstawą do weryfikacji przyjętej hipotezy oraz próby określenia roli cen i dopłat w tym zakresie.

\footnotetext{
${ }^{12}$ Współczynnik ten określa się też mianem produktu przeciętnego (Zalega 2008 str. 248) i jest to relacja niejako samodefiniująca się ze zmiennych produkcji i zatrudnienia. Relacja ta ma znaczenie dla określania źródeł wzrostu produkcji i ma charakter ilościowy, co wynika bezpośrednio z koncepcji funkcji produkcji, $\mathrm{z}$ istoty relacji ilościowej. Pozostawiamy to na boku.

${ }^{13}$ Ten współczynnik określa się jako przychód z produktu z danego czynnika (Zalega str. 416)
} 


\section{Różnice w poziomie realnej wydajności pracy}

Przyjmując powyższe sposoby określania licznika wzoru (3) zilustrujemy je po kolei. Wstępnie zilustrujemy relację:

$$
w_{L(s)}=\frac{y(s)}{L}
$$

czyli wydajność realną czynnika pracy, gdzie efekt jest określony w cenach stałych.

Wielkości uzyskane w oparciu o (4) zamieszczone są na rysunku 1. Analiza tego rysunku pozwala skonstatować, znany skądinąd fakt, bardzo dużej różnicy w poziomie tak liczonej wydajności pracy między piętnastoma krajami będącymi wcześniej członkami Unii Europejskiej, a przyjętymi do niej trzynastoma po 2004 roku $^{14}$. Różnica w wydajności pracy w 2015 roku wyniosła ponad 22 tys. euro na jednego pełnozatrudnionego w rolnictwie (tab. 1). Należy zauważyć również, że wydajność w obu analizowanych grupach krajów zwiększa się. W przypadku krajów starej UE wydajność zwiększyła się w analizowanych latach o 13,6 tys. euro na jednego pełnozatrudnionego w rolnictwie, a w przypadku grupy krajów nowoprzyjętych do UE przez 17 lat nastąpił wzrost o 4,6 tys. euro na jednego pełnozatrudnionego w rolnictwie (tab. 1).

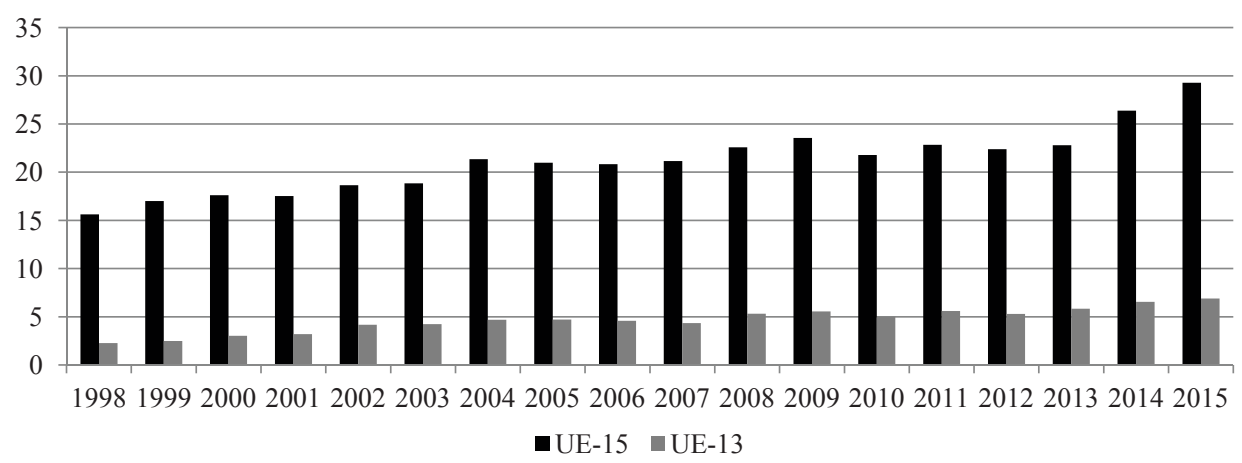

Rys. 1. Wydajność pracy w rolnictwie (wartość dodana brutto w tys. euro/ AWU) ceny stałe 2005=100, bez dopłat bezpośrednich

Fig. 1. Labour productivity in agriculture (gross value added in thousands of euros / AWU) fixed prices 2005=100, without direct payments

Źrodło: opracowanie własne na podstawie EUROSTAT: Economic accounts for agriculture - values at constant prices $(2005=100)$ [aact_eaa03], Agricultural Labour Input Statistics: absolute figures (1 000 annual work units) [aact_ali01].

Powstaje pytanie czy coś w tym obrazie zmieniają dopłaty. Mowa tu o dopłatach bezpośrednich związanych z produkcją rolniczą ${ }^{15}$. Obserwacja wizualizacji wzoru:

\footnotetext{
${ }^{14}$ Wydajność pracy w obu badanych grupach państw UE jest zróżnicowana w poszczególnych państwach UE.

15 Jako przykłady dopłat związanych z produkcją rolniczą można wymienić jednolitą płatność obszarową, oddzielną płatność z tytułu cukru (płatność cukrowa) czy płatności uzupełniające takie jak np. płatność uzupełniająca dla producentów surowca tytoniowego (płatność niezwiązana do tytoniu) oraz wsparcie specjalne jak np. specjalna płatność obszarowa do powierzchni uprawy roślin strączkowych i motylkowatych drobnonasiennych.
} 


$$
w_{L(s d)}=\frac{y(s d)}{L}
$$

pokazanej na rysunku 2, nie zmienia powyższej konstatacji. Duże różnice pod względem wydajności pozostają również i w tym ujęciu. Jednakże różnica w wydajności pracy z uwzględnieniem dopłat bezpośrednich w 2015 roku między grupami państw wyniosła prawie 25 tys. euro na jednego pełnozatrudnionego w rolnictwie i była większa od różnicy wydajności pracy bez uwzględnienia dopłat. W przypadku krajów starej UE wydajność ta zwiększyła się w analizowanych latach o 14,7 tys. euro na jednego pełnozatrudnionego w rolnictwie, a w przypadku grupy krajów nowoprzyjętych do UE o 5,2 tys. euro na jednego pełnozatrudnionego $\mathrm{w}$ rolnictwie (tab. 1). Co oznacza, iż dopłaty wpłynęły korzystnie na obie grupy państw zwiększając ich wydajność pracy, natomiast drugi wniosek płynący z analizy dotyczy negatywnego ich wpływu. Dopłaty powiększyły różnice pomiędzy analizowanymi grupami państw pod względem wydajności pracy. Może to mieć związek z większą pulą dopłat bezpośrednich do produkcji jaka przypadła grupie państw UE-15 niż UE-13

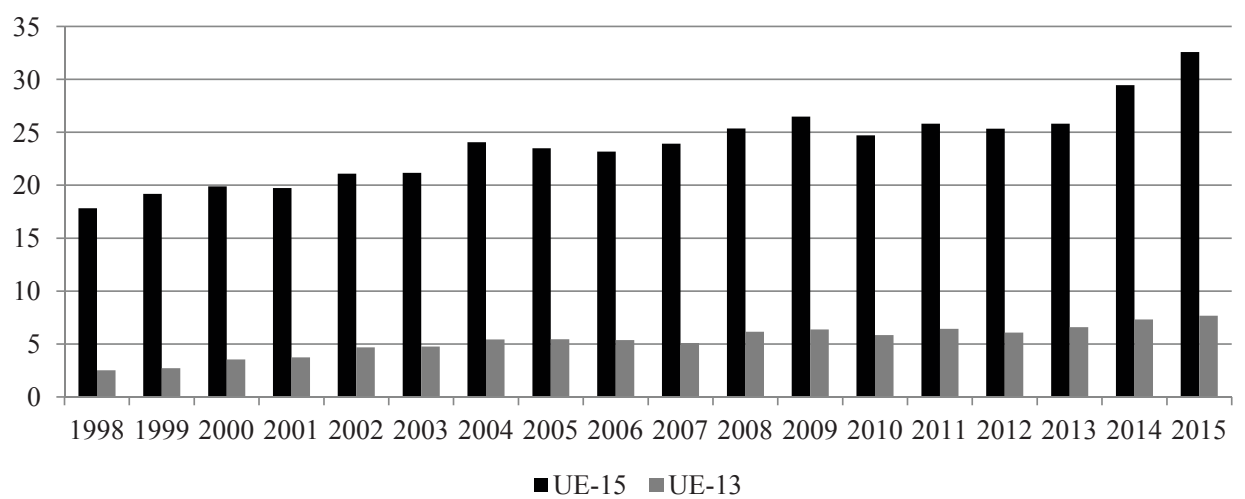

Rys. 2. Wydajność pracy w rolnictwie (wartość dodana brutto w tys. euro/ AWU) ceny stałe z roku 2005=100 z dopłatami bezpośrednimi

Fig. 2. Labour productivity in agriculture (gross value added in thousands of euros / AWU) fixed prices from $2005=100$ with direct payments

Źrodło: opracowanie własne na podstawie danych EUROSTAT: Economic accounts for agriculture - values at constant prices $(2005=100)$ [aact_eaa03], Agricultural Labour Input Statistics: absolute figures $(1000$ annual work units) [aact_ali01].

\footnotetext{
${ }^{16}$ Przy analizie grup państw UE-15 i UE-13 średnia pula dopłat bezpośrednich do produkcji była znacznie większa na korzyść państw UE-15 (ok. 7,4 razy większa pula dopłat dla państw UE-15). Jednakże po przeliczeniu wielkości dopłat bezpośrednich na 1 ha UR, dopłaty te były w latach $(2005,2007,2010,2013)$ wyższe w państwach UE-13, a w roku 2016 poziom dopłat na 1 ha uległ zrównaniu i średnio na jeden ha UR w obu grupach dopłaty bezpośrednie wyniosły ok. 135 euro.(Źródło: Eurostat Farm indicators by agricultural area, type of farm, standard output, legal form and NUTS 2 regions [ef_m_farmleg] Economic accounts for agriculture - values at constant prices $(2005=100)$ [aact_eaa03]).
} 
Zasadnicze jednak znaczenie z punktu widzenia celu naszego artykułu ma ocena czy te różnice się zmieniają i w jakim kierunku. Podstawą wnioskowania jest rysunek 3 . Analizowana jest tu wielkość wynikająca z podzielenia $w_{L}$ dla UE 15 przez $w_{L}$ dla UE 13.

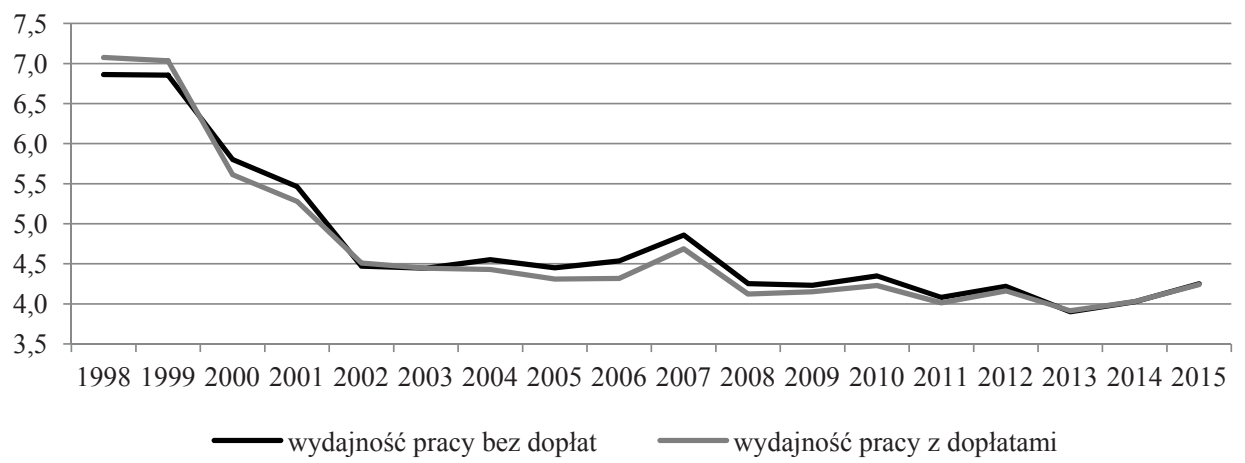

Rys. 3. Różnice w wydajności pracy w rolnictwie (w cenach stałych $(2005=100)$, z uwzględnieniem dopłat i bez dopłat bezpośrednich jako iloraz $w_{L}$ dla UE-15 i $w_{L}$ dla UE-13

Fig. 3. The differences of labour productivity in agriculture (in constant prices $(2005=100)$, including direct payments and without direct payments as a quotient in $w_{L}$ for EU-15 and $w_{L}$ for EU-13

Źrodło: opracowanie własne na podstawie danych EUROSTAT: Economic accounts for agriculture - values at constant prices $(2005=100)$ [aact_eaa03], Agricultural Labour Input Statistics: absolute figures (1 000 annual work units) [aact_ali01].

Pokazana na rysunku 3 wizualizacja pozwala zauważyć, iż zmniejszają się stopniowo dysproporcje pomiędzy wskaźnikiem wydajności niezależnie od wyrazu jego licznika. Na przykład w 1998 roku różnica między grupami państw była 6,9 i 7,1 krotna (odpowiednio WDB ceny stałe bez dopłat i z dopłatami). W kolejnych latach: 2002-2003, 2009 i 20122015, niezależnie od uwzględnienia dopłat bezpośrednich, dysproporcje te były jednakowe i zmniejszały się. W 2015 roku już tylko 4,2 krotnie państwa UE-13 miały niższą wydajność niż państwa UE-15 niezależnie czy uwzględniono dopłaty czy nie. Niewątpliwie jest to pozytywna ocena zachodzących procesów, także i najprostsza, jeśli idzie o tzw. kwestie konwergencji. Mimo pozytywnej zmiany, można zauważyć, iż dopłaty wpłynęły na zwiększenie różnic w wydajności pracy (tab. 1). Przyczyn tego zjawiska należy upatrywać w wielkości puli dopłat bezpośrednich dla grupy państw UE-15 i UE-13. Różnica między wydajnością pracy bez dopłat i z dopłatami między grupami państw powiększyła się o 2,5 tys. euro na jednego pełnozatrudnionego w rolnictwie (wzrost z 22,4 tys. euro bez dopłat do 24,9 tys. euro $\mathrm{z}$ dopłatami). Przy czym, zarówno w krajach UE-15 jak i UE-13 zaobserwowano większy wzrost wydajności pracy $\mathrm{z}$ uwzględnieniem dopłat $\mathrm{w}$ badanych latach 1998-2015 niż bez uwzględnienia dopłat. W przypadku UE-15 różnica między wzrostem wydajności wyniosła 1,1 tys. euro (wzrost z 13,6 tys. euro bez dopłat do 14,7 tys. euro $\mathrm{z}$ dopłatami) natomiast $\mathrm{w}$ grupie UE-13 odnotowano zmianę 0,6 tys. euro na jednego pełnozatrudnionego $\mathrm{w}$ rolnictwie (wzrost $\mathrm{z} 4,6$ tys. euro bez dopłat do 5,2 tys. euro z dopłatami). 


\section{Różnice w nominalnej wydajności pracy}

Powstaje kolejne pytanie czy ten obraz, co do różnic realnej wydajności czynnika pracy pomiędzy analizowanymi grupami państw UE zmieni jego ujęcie w cenach bieżących, czyli jako współczynnika nominalnej wydajności ${ }^{17}$ :

$$
w_{L(b)}=\frac{y(b)}{L}
$$

Implicite ewentualne zmiany w analizowanym zakresie można by przypisać bardziej lub mniej korzystnym zmianom cen produktów, w istocie - bardziej lub mniej faworyzującym, jedną bądź drugą grupę analizowanych krajów. Wydaje się jednak, że nie powinno to mieć miejsca, bowiem poziom cen produktów na zintegrowanym europejskim rynku rolnym winien być na podobnym poziomie. Jak widać $\mathrm{z}$ wizualizacji na rysunku 4, różnice w wydajności w analizowanym zakresie nie odbiegają zasadniczo od tych obserwowanych wyżej, nadal pozostaje bardzo wysokie (rys. 1). Dane wskazują, iż nominalna wydajność pracy $\mathrm{w}$ porównaniu do realnej $\mathrm{w}$ obu grupach państw jest wyższa. Co potwierdza wcześniejsze stwierdzenie, iż wszystkie kraje podlegają tym samym regulacjom rynkowym na wspólnym rynku. Jednakże w ostatnich dwóch latach poddanych analizie 2015 i 2016 zaobserwowano, iż wydajność nominalna pracy w krajach UE-15 była niższa niż w cenach stałych. Może to oznaczać, iż relacje cen produktów rolnych w istocie ułożyły się dla tych państw niekorzystnie. Analiza zmian w wydajności pracy w badanych latach potwierdza, iż zarówno kraje UE-15 jak i UE-13 wykazały mniejszy wzrost wydajności pracy pomiędzy rokiem 1998 a $2016 \mathrm{w}$ cenach bieżących w porównaniu do wydajności pracy w ujęciu realnym (tab. 1). Do tej konstatacji wrócimy przy analizie rysunku 5.

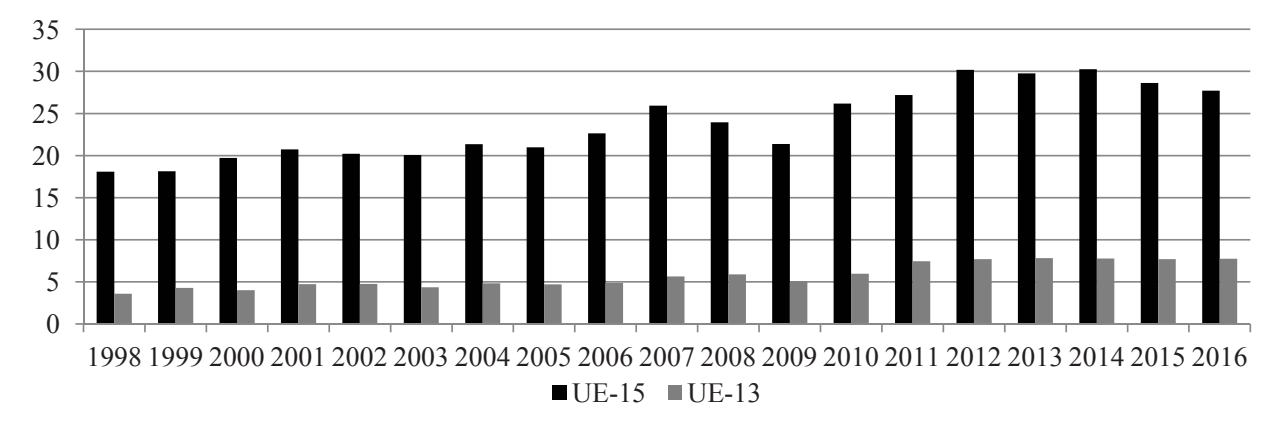

Rys. 4. Wydajność pracy w rolnictwie (wartość dodana brutto w tys. euro/ AWU) w cenach bieżących, bez dopłat bezpośrednich

Fig. 4. Labour productivity in agriculture (gross value added in thousands of euros /AWU) in current prices, without direct payments

Źrodło: opracowanie własne na podstawie danych EUROSTAT: Economic accounts for agriculture - values at current prices [aact_eaa01] i Agricultural Labour Input Statistics: absolute figures (1 000 annual work units) [aact_ali01].

\footnotetext{
17 Inaczej przychodu bieżącego z produktu czynnika pracy, trzymając się ścisłej mikroekonomii, jako źródła finansowania wynagrodzenia tego czynnika (teoria podziału).
} 
Powstaje kolejne pytanie, czy na te róznice wpłynęły zrealizowane dopłaty. Podstawą tego aspektu analizy jest następujący wzór określający nominalną wydajność pracy wraz z przeliczonymi dopłatami w cenach bieżących, czyli faktyczne źródło finansowania dochodów:

$$
w_{L(b p)}=\frac{y(b p)}{L}
$$

Jak pokazuje wizualizacja na rysunku 5, podobnie jak i na poprzednich wizualizacjach, zasadniczo utrzymują się istotne różnice w wydajności pracy.

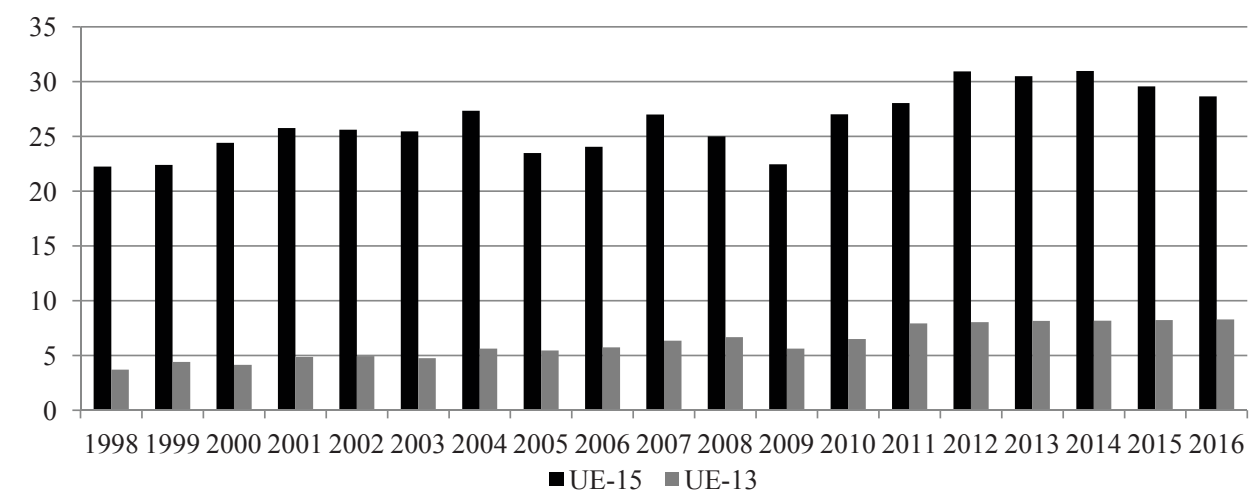

Rys. 5. Wydajność pracy w rolnictwie (wartość dodana brutto w tys. euro/AWU) w cenach bieżących z dopłatami bezpośrednimi

Fig. 5. Labour productivity in agriculture (gross value added in thousands of euros /AWU) in current prices with direct payments

Źródło: opracowanie własne na podstawie danych EUROSTAT: Economic accounts for agriculture - values at current prices [aact_eaa01] i Agricultural Labour Input Statistics: absolute figures (1 000 annual work units) [aact_ali01].

$\mathrm{Na}$ bardziej precyzyjną odpowiedź, co do zmian zróżnicowania w analizowanym współczynniku wydajności pracy pozwala analiza wizualizacji na rysunku 6 . A jest to o tyle ważne, bo w istocie ilustruje różnice, jak wspomnieliśmy, w faktycznym źródle wynagrodzenia czynnika pracy $\mathrm{w}$ analizowanych grupach krajów, zwłaszcza z uwzględnieniem dopłat. 


\section{J. Jaroszewska, W. Rembisz}

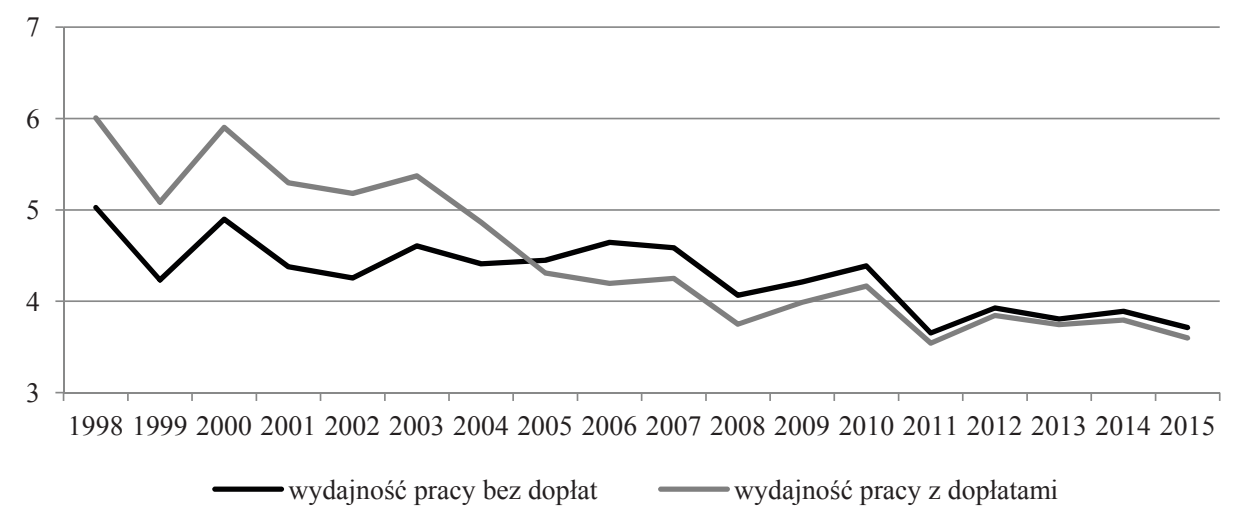

Rys. 6. Różnice w wydajności pracy w rolnictwie ( $w$ cenach bieżących z uwzględnieniem dopłat $\mathrm{i}$ bez dopłat bezpośrednich jako iloraz $w_{L}$ dla UE-15 i $w_{L}$ dla UE-13

Fig 6. The differences of labour productivity in agriculture (in current prices including direct payments and without direct payments as a quotient $w_{L}$ for EU-15 and $w_{L}$ for EU-13

Źrodło: opracowanie własne na podstawie danych EUROSTAT: Economic accounts for agriculture - values at current prices [aact_eaa01] i Agricultural Labour Input Statistics: absolute figures (1 000 annual work units) [aact_ali01].

Tutaj jest podobnie jak w przypadku wydajności w cenach stałych. Różnice W wydajności nominalnej z uwzględnieniem dopłat między grupami krajów zmniejszyły się w badanych latach z 6 krotnej do 3,6 krotnej w 2016 roku, a bez dopłat z 5 krotnej do 3,7 krotnej. Również w tym przypadku poddanym analizie dopłaty wpłynęły na zwiększenie różnic między analizowanymi grupami. Różnica $\mathrm{w}$ wydajności pracy z uwzględnieniem dopłat bezpośrednich w 2016 roku wyniosła 20,4 tys. euro na jednego pełnozatrudnionego $\mathrm{w}$ rolnictwie $\mathrm{i} \mathrm{w}$ porównaniu do różnicy $\mathrm{w}$ wydajności pracy $\mathrm{w}$ cenach bieżących bez dopłat zwiększyła się o 0,4 tys. euro na jednego pełnozatrudnionego w rolnictwie. Jest to stosunkowo mniejsza różnica niż ta zaobserwowana w cenach stałych. Może to oznaczać łagodzenie tych różnic na skutek oddziaływania rynku. W sensie ekonomicznym ocena tego może być różna, np. może to wskazywać, iż transfery unijne nie pełnią funkcji wyrównawczej, ale też na to, że dopłaty rozerwały związek wynagrodzeń z wydajnością. Na rysunku 6 widoczna jest duża rozbieżność między wydajnościami pracy w pierwszym okresie tj. do 2005 roku, należy ją łączyć z datą przystąpienia państw UE-13 do UE i objęcia ich pełnym wsparciem rolnictwa oraz jednakowym wpływem cen. 
Tabela 1. Różnice w wydajności pracy oraz zmiany wydajności pracy w latach 1998-2015 (2016) w ujęciu realnym i nominalnym z uwzględnieniem dopłat i bez dopłat bezpośrednich

Table 1. The differences of labour productivity in agriculture and changes in labour productivity in 1998-2015 (2016) in current prices and in constant prices including direct payments and without direct payments

\begin{tabular}{|c|c|c|c|c|c|c|c|}
\hline \multicolumn{2}{|c|}{ Wyszczególnienie } & \multicolumn{3}{|c|}{$\begin{array}{l}\text { Wydajność pracy realna } \\
\text { (ceny stałe) }\end{array}$} & \multicolumn{3}{|c|}{$\begin{array}{l}\text { Wydajność pracy nominalna } \\
\text { (ceny bieżące) }\end{array}$} \\
\hline & & 1998 & 2015 & UE15 - UE13 & 1998 & 2016 & UE15 - UE13 \\
\hline \multirow{3}{*}{ N $\frac{\bar{T}}{\frac{\pi}{0}}$} & UE-15 & 15,6 & 29,3 & 13,6 & 18,1 & 27,7 & 9,6 \\
\hline & UE-13 & 2,3 & 6,9 & 4,6 & 3,6 & 7,7 & 4,1 \\
\hline & UE-15 - UE-13 & 13,3 & 22,4 & - & 14,5 & 20,0 & - \\
\hline \multirow{3}{*}{ 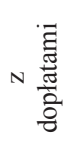 } & UE-15 & 17,8 & 32,6 & 14,7 & 22,2 & 28,7 & 6,4 \\
\hline & UE-13 & 2,5 & 7,7 & 5,2 & 3,7 & 8,3 & 4,6 \\
\hline & UE-15 - UE-13 & 15,3 & 24,9 & - & 18,0 & 20,4 & - \\
\hline
\end{tabular}

Źródło: obliczenia własne, średnie arytmetyczne dla krajów UE-15 i UE-13, na podstawie danych EUROSTAT: Economic accounts for agriculture - values at current prices [aact_eaa01], Economic accounts for agriculture values at constant prices $(2005=100)$ [aact_eaa03] i Agricultural Läbour Input Statistics: absolute figures (1 000 annual work units) [aact_ali01].

Wniosek ogólny, niezależnie od sposobu ujęcia współczynnika wydajności czynnika pracy z RER, brzmi: nadal występują bardzo duże różnice pod względem wydajności pracy między krajami UE-15 a UE-13, jednakże następuje proces jego stopniowego zmniejszania. Jest to również podstawą do powolnego wyrównywania się dochodów, co zawsze jest celem ostatecznym tzw. teorii konwergencji. Rola dopłat w wyrównywaniu poziomu wydajności pracy jest negatywna, ponieważ zwiększają one zróżnicowanie grup państw pod względem wydajności pracy. Natomiast stwierdzono poprawę tych relacji w cenach bieżących, co oznacza iż ceny produktów po objęciu państw nowoprzyjętych WPR wpływały nieco bardziej korzystnie na wydajność pracy w tej grupie.

\section{Wnioski końcowe}

Odwołując się do przyjętej hipotezy, potwierdzono znaczne różnice pod względem wydajności pracy w analizowanych grupach państw, niezależnie od ujęcia realnego, nominalnego i z i bez dopłat. Stwierdzono jednak, iż te różnice w latach 1998-2015 stopniowo się zmniejszały, zarówno w ujęciu nominalnym jak i realnym. Może to oznaczać, iż następuje proces konwergencji między tymi grupami. W badaniu odnotowano względnie korzystny wpływ cen produktów na zmniejszenie się omawianych różnic. Różnice w wydajności pracy między grupami państw zmniejszyły się w ujęciu nominalnym o ponad 1 tys. euro na osobę pełnozatrudnioną w rolnictwie. Wpływ dopłat bezpośrednich okazał się negatywny. Zarówno w ujęciu nominalnym jak i realnym, dopłaty zwiększały zróżnicowanie pod względem wydajności między analizowanymi grupami państw. Niewątpliwie należałoby w dalszych badaniach nad różnicami wydajności pracy, dokonać dezagregacji i przeprowadzić badanie na poziomie krajów. Badania te uwzględniłyby specyfikę ich rolnictwa i inne uwarunkowania. 


\section{J. Jaroszewska, W. Rembisz}

\section{Literatura}

Baer-Nawrocka, A. (2010). Zasoby pracy jako przesłanka konkurencyjności rolnictwa nowych krajów członkowskich Unii Europejskiej (Labour Force as an Evidence of the Competitiveness of Agriculture in the New European Union Member States). Roczniki Naukowe SERiA, 10(1), 16-22.

Bear-Nawrocka, A., Markiewicz, N. (2010) Zróżnicowanie przestrzenne potencjału produkcyjnego rolnictwa w krajach Unii Europejskiej (The Spacial Differentation of Agricultural Potential in EU Countries). Roczniki Nauk Rolniczych. Seria G-Ekonomika Rolnictwa, 97(4), 9-15.

European Commission, (2009). European Competitiveness Report 2008, Luxembourg, Office for Official Publications of the European Communities.

Gołaś, Z., Kozera, M. (2008). Strategie wydajności pracy w gospodarstwach rolnych (Strategies of Labour Productivity in Agricultural Farms). JARD 1(7), 73-87.

Gutierrez, L. (2000). Why is agricultural labour productivity higher in some countries than others? 2000 Annual Meeting American Agricultural Economics Association, Tampa, Florida.

EUROSTAT, http://ec.europa.eu/eurostat/data/database.

Latruffe, L. (2010). Competitiveness, Productivity and Efficiency in the Agricultural and Agri-Food Sectors, OECD Food, Agriculture and Fisheries Working Papers, No. 30, OECD Publishing. http://dx.doi.org/10.1787/5km91nkdt6d6-en.

Martín-Retortillo, M., Pinilla, V. (2012). Why did agricultural labour productivity not converge in Europe from 1950 to 2005? EHES Working Papers in Economic History, No. 25.

Misala, J., Ślusarczyk, B. (1999). Ocena międzynarodowej konkurencyjności czynnikowej Polski w okresie transformacji w świetle wyników badań empirycznych (Assessment of Poland's international factor competitiveness during the transformation period in the light of the results of empirical research). W: Handel zagraniczny - metody, problemy, tendencje. Red. K. Budzowski, S. Wydymus, Materiały VII Ogólnopolskiej Konferencji Naukowej, Kraków, 67-86.

Mrówczyńska-Kamińska, A. (2013). Wydajność pracy w gospodarce żywnościowej w krajach Unii Europejskiej (Labour Productivity in the Agri-Food Sector in the European Union Countries). Roczniki Naukowe SERiA, 15(4), 285-291.

OECD, (2011). Fostering Productivity and Competitiveness in Agriculture, OECD Publishing. http://dx.doi.org/10.1787/9789264166820-en.

Poczta, W. (2003). Rolnictwo polskie w przededniu integracji z Unią Europejską (Polish agriculture on the eve of integration with the European Union). Wyd. AR, Poznań.

Rembisz, W., Sielska, A. (2015). Mikroekonomia współczesna (Modern microeconomics). Wyd. VizjaPress@It

Zalega, T. (2008). Mikroekonomia (Microeconomics). WWZ, Warszawa.

\section{Do cytowania / For citation:}

Jaroszewska J., Rembisz W. (2018). Różnice w wydajności pracy między grupami państw UE w rolnictwie na podstawie Rachunków Ekonomicznych dla Rolnictwa (RER). Problemy Rolnictwa Światowego, 18(2), 105-116; DOI: 10.22630/PRS.2018.18.2.38

Jaroszewska J., Rembisz W. (2018). The Differences of Labor Productivity in the EU Group of Countries in Agriculture Based on Economic Accounts for Agriculture (EAA) (in Polish). Problems of World Agriculture, 18(2), 105-116; DOI: 10.22630/PRS.2018.18.2.38 